\title{
Zoledronic acid-induced orbital inflammation
}

\author{
Muhammad Faran Khalid, ${ }^{1}$ Patrick Daigle, ${ }^{2}$ Dan DeAngelis, ${ }^{2}$ \\ Jonathan Andrew Micieli (iD) 2,3,4
}

\begin{abstract}
${ }^{1}$ Michael G. DeGroote School of Medicine, McMaster University, Hamilton, Ontario, Canada ${ }^{2}$ Department of Ophthalmology and Vision Sciences, University of Toronto, Toronto, Ontario, Canada

${ }^{3}$ Division of Neurology, Department of Medicine, University of Toronto, Toronto, Ontario, Canada

${ }^{4}$ Kensington Vision and Research Centre, Toronto, Ontario,

Canada
\end{abstract}

\section{Correspondence to}

Dr Jonathan Andrew Micieli; jonathanmicieli@gmail.com

Accepted 12 August 2021

\section{Check for updates}

(c) BMJ Publishing Group Limited 2021. No commercial re-use. See rights and permissions. Published by BMJ.

To cite: Khalid MF, Daigle P, DeAngelis D, et al. BMJ Case Rep 2021;14:e245359. doi:10.1136/bcr-2021245359

\section{DESCRIPTION}

A 62-year-old man was referred for left eye redness and pain from the emergency department. He had a medical history of metastatic castrate-sensitive prostate cancer, Gleason 9, with diffuse skeletal and pulmonary metastases diagnosed 1 year prior to presentation. He received androgen deprivation therapy and a course of palliative radiation to T10, ribs and right femur. He was started on chemotherapy with docetaxel, which was completed 1 month prior to presentation. He also had type 2 diabetes mellitus, dyslipidaemia and atherosclerotic disease with an infrarenal abdominal aortic aneurysm. Medications included metformin, rosuvastatin and tamsulosin. He underwent his first infusion of zoledronic acid 3 days prior to presentation to the emergency room with left eye redness, periorbital discomfort and pain with eye movements. He was also sensitive to light and had mild blurred vision. His visual acuity was found to be 20/20 in both eyes, pupils were equal and reactive to light and there was no relative afferent pupillary defect. External examination revealed mild left ptosis, significant conjunctival injection and chemosis, and a mild diffuse limitation of eye movements in all directions in the left eye (figure 1A and B). There was $2 \mathrm{~mm}$ of left proptosis. CT orbits with contrast was performed and he was found to have fat stranding surrounding the posterior sclera and within the orbital fat. The most likely diagnosis was zoledronic acid-associated orbital inflammation and he was treated with prednisone $1 \mathrm{mg} / \mathrm{kg}$ and his symptoms promptly resolved within a few days. He was seen in follow-up 1 week later and his ocular symptoms resolved, he had no conjunctival injection and his ocular motility was normal. Zoledronic acid was discontinued.

Orbital inflammation is an increasingly recognised condition arising from the use of bisphosphonates, such as zoledronic acid. Previously, there have been a total of 28 reports of zoledronic acidinduced orbital inflammation and 39 reports of any bisphosphonate-induced orbital inflammation. ${ }^{1-27}$ Indications for bisphosphonate use included osteoporosis, Paget's disease and metastatic cancer with 8, 2 and 20 cases of orbital inflammation reported for each, respectively. Hence, the association between bisphosphonate use and orbital inflammation should be recognised by those providing the medication, ophthalmologists and emergency physicians. As was the case for our patient, orbital inflammatory disease typically presents with symptoms, such as pain and pain with eye movements, redness, diplopia and blurred vision.
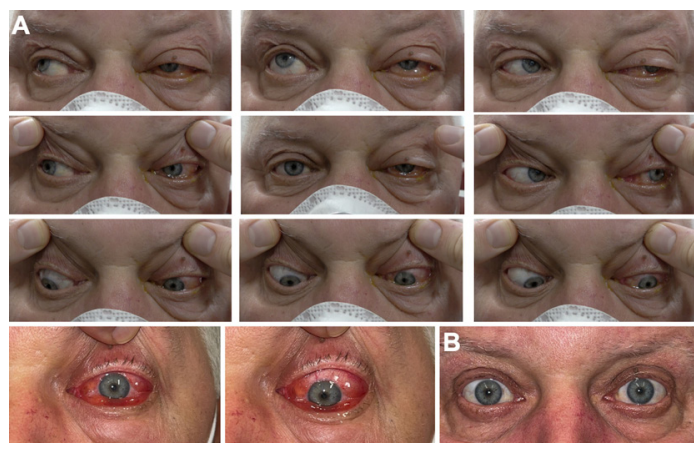

Figure 1 (A) External photographs at presentation showing mild left ptosis and a mild diffuse limitation of eye movements in all directions, and conjunctival injection and chemosis. (B) One week after initiating corticosteroids, the patient had complete resolution of signs and symptoms.

The mechanism of bisphosphonate-induced orbital inflammation includes activation of gamma delta T-cells that initiate an acute inflammatory response in extraocular muscles and release of acute-phase reactants and cytokines, such as interleukin-1 and interleukin-6. ${ }^{19}{ }^{28}$ In most cases, disease presentation was within 72 hours of medication administration when given intravenously and within 2 weeks when given orally. ${ }^{1-27}$ All patients in previous reports were treated with corticosteroids and showed good response. In most cases, bisphosphonate use was discontinued; however, rechallenge was observed in one case and led to no reoccurrence. ${ }^{2}$ Treatment, therefore, should consist of corticosteroids with further exploration into the need to discontinue the medication. Physicians should be aware of the association between bisphosphonates and inflammatory ocular disease.

Learning points

There is an association between bisphosphonate use and orbital inflammation. It is important to recognise signs, such as blurred vision, pain, pain with eye movements and eye redness.

- Our study supports the use of corticosteroids to completely resolve symptoms. Physicians should then carefully consider the risks and benefits of continuing the medication further.

Contributors Conception and design: MKF and JM. Data collection: JM. Drafting of manuscript: MFK and JM. Critical revision: MFK and JM. Final approval: JM. 
Funding The authors have not declared a specific grant for this research from any funding agency in the public, commercial or not-for-profit sectors.

Competing interests None declared.

Patient consent for publication Obtained.

Provenance and peer review Not commissioned; externally peer- reviewed.

ORCID iD

Jonathan Andrew Micieli http://orcid.org/0000-0003-4911-9152

\section{REFERENCES}

1 Polascik TJ, Mouraviev V. Zoledronic acid in the management of metastatic bone disease. Ther Clin Risk Manag 2008;4:261-8.

2 Phillips PM, Newman SA. Orbital inflammatory disease after intravenous infusion of zoledronate for treatment of metastatic renal cell carcinoma. Arch Ophthalmol 2008;126:137.

3 Herrera I, Kam Y, Whittaker TJ, et al. Bisphosphonate-Induced orbital inflammation in a patient on chronic immunosuppressive therapy. BMC Ophthalmol 2019;19:51.

4 Hsieh P-C. Effectiveness and safety of zoledronic acid in the treatment of osteoporosis. Orthopedics 2016;39:e263-70.

5 Mbekeani JN, Slamovits TL, Schwartz BH, et al. Ocular inflammation associated with alendronate therapy. Arch Ophthalmol 1999;117:837-8.

6 Umunakwe OC, Herren D, Kim SJ, et al. Diffuse ocular and orbital inflammation after zoledronate infusion-case report and review of the literature. Digit J Ophthalmol 2017;23:18-21.

7 Lefebvre DR, Mandeville JT, Yonekawa Y, et al. A case series and review of Bisphosphonate-associated orbital inflammation. Ocul Immunol Inflamm 2016;24:134-9.

8 Pirbhai A, Rajak SN, Goold LA, et al. Bisphosphonate-Induced orbital inflammation: a case series and review. Orbit 2015;34:331-5.

9 Ryan PJ, Sampath R. Idiopathic orbital inflammation following intravenous pamidronate. Rheumatology 2001;40:956-7.

10 Subramanian PS, Kerrison JB, Calvert PC, et al. Orbital inflammatory disease after pamidronate treatment for metastatic prostate cancer. Arch Ophthalmol 2003:121:1335

11 Sharma NS, Ooi J-L, Masselos K, et al. Zoledronic acid infusion and orbital inflammatory disease. N Engl J Med 2008;359:1410-1.
12 Seth A, Anderson DP, Albiani DA, et al. Orbital inflammation and optic neuropathy with zoledronic acid for metastatic prostate cancer. Can J Ophthalmol 2009:44:467-8.

13 Missotten G, Verheezen Y. Orbital inflammation after use of zoledronic acid for metastasized prostate carcinoma. Bull Soc Belge Ophtalmol 2010;315:23-4.

14 Procianoy F, Procianoy E. Orbital inflammatory disease secondary to a single-dose administration of zoledronic acid for treatment of postmenopausal osteoporosis. Osteoporos Int 2010;21:1057-8.

15 Yang EB, Birkholz ES, Lee AG. Another case of bisphosphonate-induced orbital inflammation. J Neuroophtha/mol 2010;30:94-5.

16 Yeo J, Jafer AK. Zolendronate associated inflammatory orbital disease. N Z Med J 2010;123:50-2.

17 Kaur H, Uy C, Kelly J, et al. Orbital inflammatory disease in a patient treated with zoledronate. Endocrine Practice 2011;17:e101-3.

18 Ortiz-Perez S, Fernandez E, Molina JJ, et al. Two cases of drug-induced orbital inflammatory disease. Orbit 2011;30:37-9.

19 Schwab P, Harmon D, Bruno R, et al. A 55-year-old woman with orbital inflammation. Arthritis Care Res 2012;64:1776-82.

20 Böni C, Kordic H, Chaloupka K. Bisphosphonate-associated orbital inflammatory disease and uveitis anterior--a case report and review. Klin Monbl Augenheilkd 2013;230:367-9.

21 Peterson JD, Bedrossian EH. Bisphosphonate-associated orbital inflammation--a case report and review. Orbit 2012;31:119-23.

22 Manuylova E, Clark N, Shafiq I. Orbital pseudotumor in a patient treated with zoledronic acid: a case report and pertinent literature review. AACE Clin Case Rep 2016;2:e106-9.

23 Rahimy E, Law SK. Orbital inflammation after zoledronate infusion: an emerging complication. Can J Ophthalmol 2013;48:e11-12.

24 Chehade LK, Curragh D, Selva D. Bisphosphonate-Induced orbital inflammation: more common than once thought? Osteoporos Int 2019:30:1117-20.

25 Tan M, Kalin-Hajdu E, Narayan R, et al. Zoledronic acid-induced orbital inflammation in a patient with multiple myeloma. J Oncol Pharm Pract 2019;25:1253-7.

26 Muruganandam M, Sandhu H. Orbital inflammation secondary to zoledronic acid, a rare presentation. J Clin Rheumatol 2016;22:384.

27 Vora MM, Rodgers IR, Uretsky S. Nitrogen bisphosphonate-induced orbital inflammatory disease: gamma delta T cells--a report and review of 2 cases. Ophthalmic Plast Reconstr Surg 2014;30:e84-5.

28 Rossini M, Adami S, Viapiana O, et al. Acute phase response after zoledronic acid is associated with long-term effects on white blood cells. Calcif Tissue Int 2013;93:249-52

Copyright 2022 BMJ Publishing Group. All rights reserved. For permission to reuse any of this content visit

https://www.bmj.com/company/products-services/rights-and-licensing/permissions/

BMJ Case Report Fellows may re-use this article for personal use and teaching without any further permission.

Become a Fellow of BMJ Case Reports today and you can:

Submit as many cases as you like

- Enjoy fast sympathetic peer review and rapid publication of accepted articles

Access all the published articles

- Re-use any of the published material for personal use and teaching without further permission

Customer Service

If you have any further queries about your subscription, please contact our customer services team on +44 (0) 2071111105 or via email at support@bmj.com.

Visit casereports.bmj.com for more articles like this and to become a Fellow 


\section{Correction: Zoledronic acid-induced orbital inflammation}

Khalid MF, Daigle P, DeAngelis D, et al. Zoledronic acid-induced orbital inflammation. BMJ Case Rep 2021;14:1-2. doi: bcr-2021-245359

This article was previously published with errors in authorship. Please see below changes: Dan DeAngelis and Patrick Daigle are added prior to author Jonathan Andrew Micieli. They are affiliated to the Department of Ophthalmology and Vision Sciences, University of Toronto, Toronto, Ontario, Canada.

Case reports provide a valuable learning resource for the scientific community and can indicate areas of interest for future research. They should not be used in isolation to guide treatment choices or public health policy.

C) BMJ Publishing Group Limited 2022. No commercial re-use. See rights and permissions. Published by BMJ.

BMJ Case Rep 2022;15:e245359corr1. doi:10.1136/bcr-2021-245359corr1

D) Check for updates

Copyright 2022 BMJ Publishing Group. All rights reserved. For permission to reuse any of this content visit https://www.bmj.com/company/products-services/rights-and-licensing/permissions/

BMJ Case Report Fellows may re-use this article for personal use and teaching without any further permission.

Become a Fellow of BMJ Case Reports today and you can:

- Submit as many cases as you like

- Enjoy fast sympathetic peer review and rapid publication of accepted articles

- Access all the published articles

- Re-use any of the published material for personal use and teaching without further permission

Customer Service

If you have any further queries about your subscription, please contact our customer services team on $+44(0)$ 2071111105 or via email at support@bmj.com.

Visit casereports.bmj.com for more articles like this and to become a Fellow 